\title{
GCU
}

Glasgow Caledonian

University

University for the Common Good

\section{Balancing the books: creating a model of responsible fashion business education}

Radclyffe-Thomas, Natascha; Varley, Rosemary; Roncha, Ana

Published in:

Art Design and Communication in Higher Education

DOI:

10.1386/adch.17.1.89_1

Publication date:

2018

Document Version

Author accepted manuscript

Link to publication in ResearchOnline

Citation for published version (Harvard):

Radclyffe-Thomas, N, Varley, R \& Roncha, A 2018, 'Balancing the books: creating a model of responsible fashion business education', Art Design and Communication in Higher Education, vol. 17, no. 1, pp. 89-106. https://doi.org/10.1386/adch.17.1.89_1

\section{General rights}

Copyright and moral rights for the publications made accessible in the public portal are retained by the authors and/or other copyright owners and it is a condition of accessing publications that users recognise and abide by the legal requirements associated with these rights.

Take down policy

If you believe that this document breaches copyright please view our takedown policy at https://edshare.gcu.ac.uk/id/eprint/5179 for details of how to contact us. 


\section{IFFTI 2017 Breaking the Fashion Rules}

Fashion rule broken: Fashion business should not be driven by the bottom line.

Title: Balancing the books: Creating a model of responsible fashion business education Theme: Fashion business models. Sub theme: Business models.

Key words: business, education, ethics, fashion, sustainability

Corresponding author: Dr Natascha Radclyffe-Thomas, Course Leader BA Fashion Marketing, London College of Fashion, 272 High Holborn London WC1V 7EY. n.radclyffethomas@,fashion.arts.ac.uk +44(0)7768040818.

Co-author: Dr Ana Roncha, Course Leader Strategic Fashion Marketing, London College of Fashion, 20 John Princes Street, London W1G 0BJ. a.roncha@fashion.arts.ac.uk

Co-author: Rosemary Varley, Subject Director Marketing and Retail, London College of Fashion, 272 High Holborn, London WC1V 7EY. r.varley@,fashion.arts.ac.uk

'Alumni of London College of Fashion's Fashion Business School will be making decisions in the fashion industry of the future, and it's important that we introduce them to some of the challenges of the fashion industry in order for them to develop their ethical stance on issues like sustainability'

Dr. Natascha Radclyffe-Thomas, Green Gown Awards (2015)

\section{Introduction}

The fashion industry has well-documented challenges around sustainability; the predominance of the low-cost-high-turnover business model raises questions about fashion's ethics (Shaw et al., 2004). Fashion's engagement with sustainability is most visible in design and production areas and is much less well developed in socially-responsible management, although integrating ethical business and sustainability into graduates' attributes is increasingly seen as a priority for educators ( Brinkmann, et al., 2011). With our position as fashion business educators we have a responsibility to guide students as they develop their positions on the serious issues the fashion industry faces today. This paper explores a series of curriculum interventions at undergraduate and postgraduate level which introduce London College of Fashion Business School students to complex practical and ethical challenges for $21^{\text {st }}$ century fashion businesses, using the lens of sustainability to explore every aspect of the fashion industry: production, design and promotion. Through the authors' research and teaching, case studies, lectures, seminars and assessment tasks have been designed to engage students with curriculum projects with a 360-degree understanding of sustainability and to promote students' development of creative solutions to our industry's challenges. In the innovative fashion business curriculum examples explored in this paper, our research and teaching aims to find and respond to an increased interest in concepts of shared value (Porter \& Kramer, 2011) particularly evident in new generations of students (Jarvis, 2016).

\section{Fashion and sustainability}

Traditionally the fashion industry has had a glamorous image, with its creativity, sensuality and celebrity associations. In recent years, however the glitz that masks the social and environmental impacts associated with the production of fashion garments has begun to be 
eroded with the industry attracting negative publicity for poor working conditions and environmental damage. Fashion industry stakeholders including designers, fashion journalists and consumers have questioned the necessity and even the sanity of designers showing multiple shows per year and stores receiving weekly deliveries. Fashion has become synonymous with change and a central strand of fashion business is to continue generating consumer needs and wants. The latter $20^{\text {th }}$ century saw mass industrialization of fashion production with extended supply chains that too often have necessitated intensive textile and garment production methods to meet competitive cost targets. The fashion industry facilitated a race-to-the-bottom prioritizing profit margins and return on investment with little regard to social and environmental impacts (Shaw et al., 2004).

Regrettably, avoidable large scale industrial accidents are still occurring; the widely acclaimed documentary The True Cost (released in 2015) highlighted the systemic damage resulting from the fast fashion system, and led to increased calls for transparent supply chains and commitments from fashion businesses to hold themselves to higher ethical standards. As highlighted by Moisander and Pesonen (2002), sustainable purchasing starts with consumer knowledge and consumers can drive the necessary changes in the industry. Educating consumers and empowering them to make the right choices was discussed by Fletcher (2008) under the Slow Fashion movement that advocates an emergence of social consciousness on a global base. Empowering consumers is directly connected to their knowledge of environmental issues. Through consumer involvement, higher loyalty is achieved as well as brand awareness and positive word-of-mouth communications. This can lead to competitive advantages and to maximization of a sustainable profitability (Storbacka et al., 1994; Yeung et al., 2002).

However, as the business case for sustainability becomes stronger, Barber et al (2014) outline the paradigm for business schools framing their sustainable education offer: whilst a large body of students believe that the for-profit sector should address social and environmental issues and see themselves as future agents of change, others see the business school as a fasttrack to management employment and are desirous of a curriculum that focusses exclusively on professional skills and knowledge and not spending time exploring 'environmental problems, global responsibility and intergenerational concerns' (2014:475). It is against this backdrop that the role of fashion business education is changing.

\section{Sustainability literacy and transformational business education}

One approach to sustainable and ethical business education that Robinson (2009) has called 'a greening business approach' provides a value chain of sustainable education. By engaging students' interest in sustainability, educators help them recognise the links between sustainability and their own future careers, and how in their own future work lives they may influence business decision making. This awareness and empowerment may in turn help students feel more optimistic about both organizational and environmental change and live more fulfilled sustainable lives. The literature on sustainable and responsible pedagogy increasingly refers to the need for educators to foster learning environments which enable students to develop sustainability literacy ${ }^{l}$ a term defined by Stibbe and Luna (2009:2) as 'the

\footnotetext{
${ }^{1}$ The discussion of sustainability literacy is grounded within a wider understanding of literacy which goes beyond a binary can/cannot and is understood rather to mean one who is 'empowered to read self and society critically, to discover insights into the trajectory of society and to envisage where it is heading' (Stibbe \& Luna, 2009:2).
} 
skills, attitudes, competencies, dispositions and values' deemed necessary to mitigate 'the declining conditions of the world'. To facilitate such sustainability literacy, Stibbe and Luna propose active learning incorporating 'self-reflection, self-directed enquiry, learning by doing, engagement with real-life problems and issues, and learning within communities' (2009:2).

The 2007 United Nations Principles for Responsible Management Education are an engagement framework for Higher Education Institutions to embed CSR in education, research, and campus practices (unprme.org). This Global Compact initiative was developed in response to the global economic crisis, as a framework against which business schools can audit progress towards a societally responsible curriculum and practices. Purpose, the first of the six Principles, challenges educators to develop their students' capabilities 'to be future generators of sustainable value for business and society and to work for an inclusive and sustainable global economy' (unprme.org).

In August 2016, the PRME Secretariat reported the findings of the third international survey of business students' attitudes towards responsible management education and CSR. The global survey showed respondents overwhelmingly believe business students should study business ethics, environmental sustainability and how businesses can assist in the achievement of the UN's Sustainable Development Goals (SDGs) (79\%, 76\% and 75\% respectively). Additionally, responses showed that increasingly students want to work for 'genuinely responsible and sustainable companies' (UNPRME News 2016). Yet despite higher education's recent focus on graduate employability data and evidence that graduates can differentiate themselves from their peers through the acquisition of sustainable literacy skills, there is little sign of its inclusion in mainstream education (Barber et al (2014); Robinson, 2009). Robinson (2009) argues that the inclusion of sustainability literacies is both necessary and unavoidable if educators wish to see their students becoming agents of change who can identify opportunities and implement strategies that will contribute to future environmental and sustainability improvements. Goldberg (2009) outlines key areas of sustainability literacy which should be included in the curriculum which encompass both specific scientific (climate change), and legislative (national and international requirements) knowledge, as well as more general employability skills especially regarding researching, building and proposing arguments for organizational change.

With many fashion business curricula designed to reflect the predominant business discourse, the responsibility of incorporating sustainability and business ethics into schemes of work is often left to a small core of passionate and/or specialist educators. In the absence of a large body of prior pedagogy to draw upon the topics inherent in sustainability and ethical education can become overwhelming for teachers as well as students. Goldberg (2009) highlights that although many people (students) may be passionate about similar issues (e.g. sustainability and ethics), it is necessary to unpack why, how and about what, others are enthused, as without this knowledge their actions and motivations may be misunderstood. Goldberg proposes teachers encourage students to identify their personal values and motivations by referring to a model of 'social conscience' to support the development of their sustainability literacy. In this conception social conscience is understood as an interconnected framework combining an individual's consciousness (knowledge and awareness of issues), structure (understanding of societal systems and structures) and agency (students' sense of personal power) and where students can judge their own position with regards to awareness of 
injustice, designation of responsibility and willingness and/or ability for action (Goldberg, 2009).

For Hicks (in Wayman 2009) the core pedagogic question for educators is how to engage students in a 'liberating and empowering' learning process, suggesting that working with sustainability case studies and directing students to philosophical and practical resources' teachers can avoid adopting a prescriptive position, and rather allow students to envision actions with regards to sustainability.

\section{Method}

The following single-setting case studies present an overview and investigation into the authors' development of responsible management curriculum at London College of Fashion's Fashion Business School. It explores the motivation behind a series of curriculum interventions designed to promote engagement with business ethics generally and sustainable fashion specifically. A case study method was adopted to record and analyze our experiences (Yin, 2003), adopted to develop detailed knowledge about one specific institution (Hammersley, 1998) with the aim of generating practical teaching and learning applications in our own institution (Roberston et al, 2000) but also to inform understandings of the wider higher education landscape (Basit, 2003) and contribute to the literature on sustainability and ethics in higher education.

Each case study introduces the context of the course and the types of curriculum intervention implemented between 2012 and 2016. All the authors hold teaching posts in the Fashion Business School and have a shared research interest in sustainability, business ethics and innovative business models. In undertaking these curriculum projects the authors' aims aligned with our institutional values Fashion means business: to nurture creative leaders and thinkers who work in responsible, analytical and ingenious ways and Fashion shapes lives: through teaching, specialist research, and collaborative work, we empower our students to think differently, using fashion to examine the past, build a sustainable future, and improve the way we live (http://www.arts.ac.uk/fashion/about/).

The specific aims of this case study research were multiple: to gauge students' level of interest and knowledge of sustainability and business ethics, to understand their perceptions of existing curricula in these areas, to record sustainability curriculum interventions, and in the case of the BA (Hons) Fashion Marketing cohort, to measure the impact of a fully immersive sustainability and business ethics unit. The qualitative and quantitative data included in this paper were collected by the authors through surveys and from students' unit evaluations and personal and professional development reflective statements. As the researchers were particularly interested to uncover our students' background, personal values, worldview and sense of agency regarding sustainability and business ethics, questions were incorporated to prompt students to articulate their personal understandings, values and motivations in line with Goldberg's (2009) model of social conscience. Students were asked to respond to word associations for sustainability and ethics, to report on their own level of interest in ethical and sustainable fashion, on the extent of focus on sustainable fashion in their course, on their understanding of ethical and sustainability issues in the fashion industry and their confidence to discuss these in a job interview. A mixed design for the questionnaires was implemented using scaling for most of the questions on the first questionnaire (circulated 
to undergraduate and postgraduate courses) and open questions for the second one (only circulated to BA (Hons) Fashion Marketing students.

\begin{tabular}{|l|l|}
\hline Scale Questions & Scale 1-10 \\
\hline $\begin{array}{l}\text { 4. On my course so far I consider the focus on sustainable } \\
\text { fashion to have been: }\end{array}$ & A little-A lot \\
\hline $\begin{array}{l}\text { 5. As a fashion student I feel my knowledge about } \\
\text { sustainable fashion is: }\end{array}$ & Low-High \\
\hline $\begin{array}{l}\text { 6. I feel my understanding of ethical and sustainability } \\
\text { issues in the fashion industry is: }\end{array}$ & $\begin{array}{l}\text { Superficial-Detailed } \\
\text { in-depth }\end{array}$ \\
\hline $\begin{array}{l}\text { 7. As a person my interest in ethical and sustainable } \\
\text { fashion is: }\end{array}$ & Low-High \\
\hline $\begin{array}{l}\text { 8: If I were questioned about ethics and sustainability in a } \\
\text { job interview I would feel: }\end{array}$ & $\begin{array}{l}\text { Unable to answer- } \\
\text { Confident to answer }\end{array}$ \\
\hline
\end{tabular}

Table 1 Summary of Start of unit questionnaire scale questions

In total 78 postgraduate and 111 undergraduate students were surveyed in a start of unit questionnaire across five courses with the BA (Hons) Fashion Marketing students being surveyed additionally at the end of their unit. The data was analysed by the authors and is reported below.

\section{The Cases}

\section{Sustainability in Fashion Design and Marketing}

Working with BA (Hons) Fashion Design and Marketing students provided an opportunity to develop a holistic project using the lens of sustainability to look at each aspect of the fashion industry. This project ran for 10 weeks in the autumn term in 2013 (approximately 20 students), 2014 (approximately 20 students), and 2015 (approximately 30 students) when one of the authors co-taught a final year undergraduate unit Fashion Marketing Specialism. This course is unusual in that it combines both discipline areas of design and marketing in one degree and although sustainability is one of London College of Fashion's core values and as such it is often referred to in terms of product and design, there has been less emphasis on how students can engage with sustainability issues through business. Initial talks with LCF's Centre for Sustainable Fashion (http://sustainable-fashion.com) introduced the author to using case studies and future scenarios and to a set of business-focused teaching resources which became the foundation for how sustainability was incorporated.

The author developed a challenging assignment that involved which included a series of guest lectures from sustainability champions after which students carried out sustainability audits on London-based start-up fashion brands and proposed design and marketing strategies for these using sustainability as a key source of differentiation and added value. The curriculum included: textile waste, no-waste design, sustainability and design aesthetics, ethical and business drivers, co-creation, green marketing, competitive advantage and transparency and included mini case studies on ethical fashion brands. Guest speakers added legitimacy and current industry knowledge including a speaker from the British Fashion Council who highlighted their ethical initiatives. Other guest speakers included the marketing manager from the Hong Kong based textile-waste charity Redress who introduced their work and unpacked their marketing strategy. A current UAL PhD candidate working on sustainable nowaste design presented her practice-based work in the design studio. Although students 
reported that this was a challenging unit, engagement was high and students responded positively:

'The sustainability part of this project has changed the way in which I look at fashion due to my heightened awareness of the sustainable issues affecting fashion' (Unit evaluation).

Many students commented that participating in this unit was the first time they had felt engaged with marketing:

'Sustainability has been an aspect of business in which I had been interested previously, however this project introduced new aspects of sustainability, such as the wide variety of sustainable fabrics, as well as ways of promoting sustainability, such as co-creation. I found this discovery very interesting, as I used to think that sustainability was mainly in the production of garments, such as lower carbon emissions... This is an area of interest which may be carried to future projects both during the course and once I've gained employment.' (Personal Professional Development statement).

The project was included in a joint submission for the 2015 Environmental Association for Universities and Colleges (EAUC) national teaching and learning awards under the Continuing Improvement category and was a finalist at their 2015 Green Gown Awards.

\section{Teaching with Case Studies}

For many years, the flagship undergraduate BA (Hons) Fashion Management course has used a case study teaching and learning approach for strategic fashion management studies. Having found a lack of extensive, fully integrated case study resources for fashion management students, the case studies have been written in-house. Case companies are selected to reflect contemporary and topical issues and have covered all fashion market levels. In 2015 Patagonia was chosen by one of the authors who leads this unit, for its managerial focus on sustainability, and for its interesting crossover from extreme sports clothing to the heights of cool (Lutz, 2011). Although the use of a sustainable brand supports the PRME principles, in this instance the course team expressed some concerns about whether Patagonia would be acceptable to the students as a fashion brand. To help justify the choice of case company students were invited to a showing of The True Cost which presents a compelling argument and vivid justification for the focus on sustainability in fashion. Course feedback indicated strong support for the choice of company, with 'the case company' being the most frequently mentioned positive point in students' individual unit evaluations.

Building on the success of this unit, a similar teaching strategy was adopted for a new unit designed for the first cohort of the BA (Hons) Fashion Marketing course developed and delivered by two of the authors. The case was supported by extensive background knowledge of the brand and the authors' desire to introduce students to the ethical and sustainable concepts inherent in social enterprise. This curriculum project based on the authors' research into innovative business models, uses their case study on social enterprise as the basis for a Fashion Marketing Strategy unit which uses real fashion industry examples, including our own alumni, to encourage debate about fashion's difficult questions- the balance between economic, social and environmental sustainability. The authors have been involved in longitudinal research on the TOMS for-profit social enterprise brand since 2013 and this research has allowed a deep immersion in the brand's business model and marketing strategies, including international field research and access to key informants in both the retail 
and giving departments. The authors' recently published TOMS' case study (RadclyffeThomas and Roncha, 2016) was integrated into the teaching, learning and assessment approach with a series of lectures, seminar activities and field trips to the TOMS London flagship. Although similar in flavour the case study method was unique to each of the courses and differed in assessment method and coverage as shown in Table 2.

\begin{tabular}{|l|l|l|l|l|l|}
\hline Course & Unit & $\begin{array}{l}\text { Credit } \\
\text { worth }\end{array}$ & Assessment & $\begin{array}{l}\text { Case } \\
\text { length }\end{array}$ & Use of case \\
\hline $\begin{array}{l}\text { BA (Hons) } \\
\text { Fashion } \\
\text { Management }\end{array}$ & $\begin{array}{l}\text { Strategic } \\
\text { Fashion } \\
\text { Management }\end{array}$ & 40 & $\begin{array}{l}\text { Exams } \\
(2 \text { papers })\end{array}$ & 40 pages & $\begin{array}{l}\text { Used to } \\
\text { contextualize } \\
\text { theory } \\
\text { towards end } \\
\text { of unit and } \\
\text { in } \\
\text { assessment }\end{array}$ \\
\hline $\begin{array}{l}\text { BA (Hons) } \\
\text { Fashion } \\
\text { Marketing }\end{array}$ & $\begin{array}{l}\text { Strategic } \\
\text { Fashion } \\
\text { Marketing }\end{array}$ & 20 & $\begin{array}{l}\text { Exam } \\
(1 \text { paper })\end{array}$ & 10 pages & $\begin{array}{l}\text { Used as } \\
\text { teaching } \\
\text { vehicle } \\
\text { through unit }\end{array}$ \\
\hline
\end{tabular}

Table 2

One of the desired outcomes of sustainability literacy is the ability to form and present convincing policy arguments and as such seminar activities included working through a mini case study requiring critiques and development proposals for the brand, a debate on the merits of social enterprise and guest speakers who are running their own start-up social enterprises in Europe and Asia.

For BA (Hons) Fashion Marketing the authors anticipated and encountered a level of scepticism about social enterprise in general and the TOMS brand in particular. At the start of the unit some students questioned the motivation of social entrepreneurs, were unconvinced by TOMS' business model and felt these to be marketing ploys. As the unit progressed and students become more familiar with the case and participated in a store visit and talk from the UK Marketing Manager, and a Giving Talk from the Director of Social Innovation, there was an indication that a shift in attitude was taking place. To investigate and gauge the extent of this change, two questionnaires were administered to the group, at the start and at the end of the unit. The end of unit questionnaire included free-text reflective responses and repeated Question 8 from the start of unit asking about students' confidence discussing ethical and sustainable issues in a job interview which would indicate transformational learning. The total number of usable responses for the BA (Hons) Fashion Marketing students were 53 for the start of the unit and 35 for the end of unit.

\section{Sustainability and ethics in the postgraduate classroom}

When referring to the postgraduate courses - specifically the MA in Strategic Fashion Marketing - although there is not a dedicated unit on sustainability, these topics and business approaches are spread across a variety of units. Throughout the three stages of the course (September to January; February to June and June to September) students engage in case study discussions; role plays; guest lecturer sessions; presentations; reports, business and communication plans for/ about sustainable business models and/ or brands whose efforts are 
recognized for engaging with such issues and adopting policies of responsible innovation/ price and supply chain transparency.

The postgraduate students involved in this curriculum project are studying on MA Strategic Fashion Marketing, MA Fashion Retail Management and MA Fashion Design Management and participated in a guest lecture and seminar session given by one of the authors as part of a stage one Fashion Branding unit. A lecture on ethics and sustainability introduced students to relevant legal and regulatory frameworks, social and environmental impact, marketing strategy and consumer behaviour theory as well as multiple case studies of social enterprises. The lecture was followed by a seminar session using the authors' TOMS' mini case-study as a teaching tool. There has been a substantial increase in the number of students willing to explore such topics in their final dissertation. For the current cohort alone, around $25 \%$ of students have demonstrated willingness to choose sustainability as the core focus for their final major project.

\section{Sustainable fashion international collaboration}

In addition to these curriculum projects a small number of Fashion Business School students were invited to participate in an extracurricular sustainable fashion collaboration with students from the Copenhagen School of Design and Technology (KEA) hosted in London over three days in December 2016. The underlining concept behind the LCF/ KEA collaboration was to bring students from fashion and business courses together to empowering them with knowledge and allow their creativity to expand and inform the creation of ambitious goals and objectives. Entitled Fashion narratives for the future it aimed to create new ideas and narratives based on the United Nations' 17 SDGs which represent a shift in business culture, strategy, design, communication and production processes. The purpose of this collaboration was for students to share knowledge, skills and competences to develop and propose new sustainable opportunities and design solutions as well as to define a new eligibility for fashion now and in the future (KEA, 2016).

Cross-disciplinary collaboration is a key means to make change around sustainability. The diversity in backgrounds is understood as an effective way to achieve value-added collaborations. Different educational programmes and schools are put together and represent the driving force of this project together with actors from the fashion industry. Through featuring a high-profile fashion company (Vivienne Westwood) students were given the task of bringing the SDGs into the business, by coming up with a framework, concept or design solution routed in both the SDGs as well as the partner company's DNA.

The London workshop started with students from each institution being split into a total of seven mixed groups and given a theme to work on. These themes, devised by the KEA partner tutors, combined two to three of the SDGs. Tutors from KEA and facilitated discussions and helped unleash students' thoughts and ideas on issues such as: where will the industry be in ten years' time? what are the implications of today's actions in our future lives? how can different stakeholders influence and play a role in changing the industry? LCF tutors were invited to support the process and content which were based on the work and concepts developed at The Youth Fashion Summit held as part of the Copenhagen Fashion Summit in early 2016.

\section{Key findings and discussion}


As stated previously the authors were interested in students' opinions and values concerning fashion sustainability and business ethics, with their perception of their higher educational experiences and in the impact of our curriculum projects on such. In reviewing the Start of Unit questionnaire responses several themes emerged.

Regarding the free-text responses (see Table 3) about sustainability the majority of students saw this as closely linked to values, being the right thing to do, they were also conscious of sustainability's temporal relevance of futures including their own, the fashion industry's and the planet's as evidenced in this response:

'It will influence the fashion future in the next twenty years so that will influence my career life.'

Students associated ethics with both values, caring (about animals, the environment and humanity) and business philosophy (corporate social responsibility) and with lived experience of fashion industry workers showing concern for working conditions especially child labour and sweatshops as evidenced in this response:

'Ethical and sustainable fashion is produced by adult workers, in a clean workspace with materials that can be sourced in a sustainable way. Workers receive a fair wage and have the right to form unions.'

\begin{tabular}{|l|l|}
\hline Free text Questions all students & Most frequent response \\
\hline Sustainability & Environment \\
& Ethical \\
& Future \\
& Recycle \\
& Responsibility \\
\hline Ethical/ethics & Environment \\
& (Child) labour \\
& Moral \\
& Philosophy \\
& Respect \\
& Responsibility \\
& Sustainable \\
\hline
\end{tabular}

Table 3

In the scale question Start of unit responses using a scale of 1 to 10, the authors interpreted responses in the 1-5 region as negative and those in the 6-10 region as positive. By applying this to Question 7 (see Table 4) the authors judged students' self-reported level of interest in ethical and sustainable fashion to be generally positive. One stand-out result was that for the BA (Hons) Fashion Management cohort, despite the course team's initial hesitancy, the results of the start of unit survey showed a high level of personal interest in ethical and sustainable fashion with the mode score being 10 . 


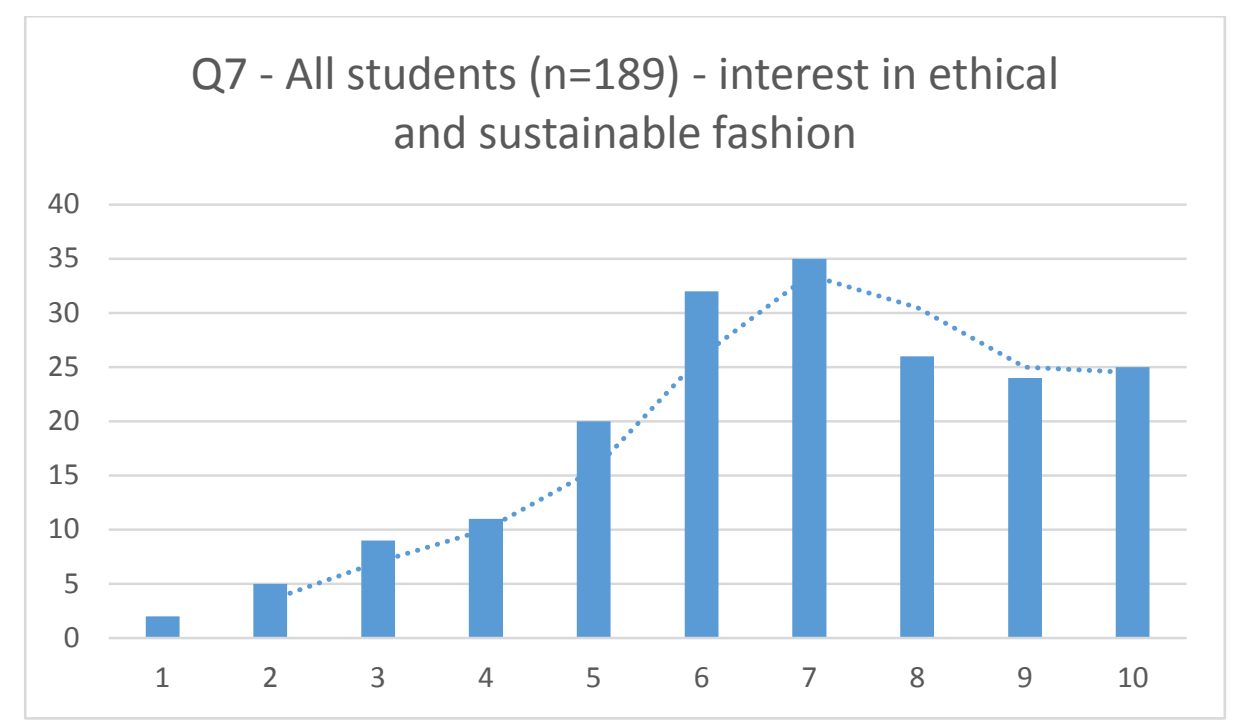

\section{Table 4}

The authors used combined responses to show students' perception of fashion education (Questions 4 and 5), of the fashion industry (questions 6 and 8) and self-perceived knowledge and understanding (Questions 5,6 and 8). An unsurprising result was that for all but one of the courses involved in the study students' responses to questions about their ethical and sustainable fashion education resulted in a normal distribution (see Table 5), this may be as a result of each students' own motivation to engage with educational resources and/or a lack of ability to compare their own educational experiences with peers studying at other higher education institutions.

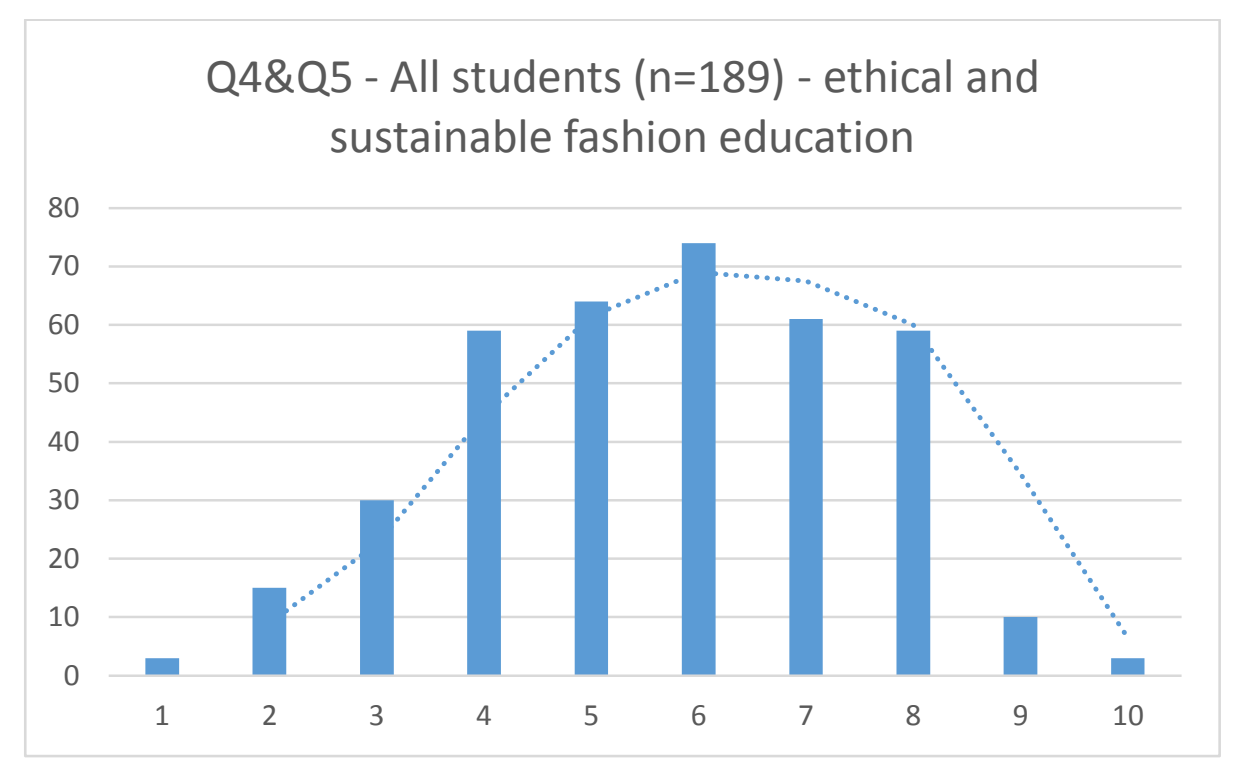

Table 5

Question 8 asked students' to self-reported their confidence level if asked to respond to job interview questions about ethics and sustainability. The End of the unit questionnaire (circulated to BA (Hons) Fashion Marketing students only) repeated this question and the results can be seen below in Table 6 with a shift from $43.4 \%$ positive responses to $77.8 \%$ positive responses seen as an indication of transformational learning. 


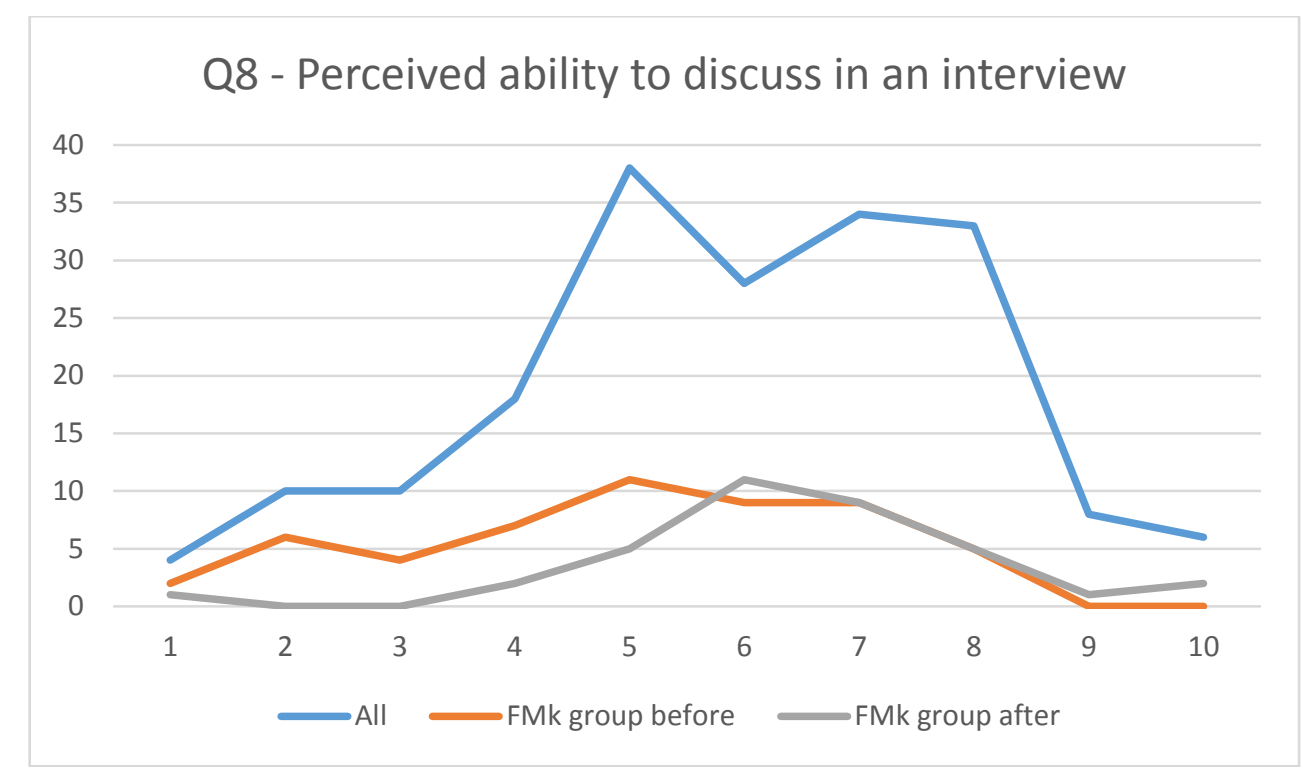

Table 6

Additionally, reviewing the free text responses to the End of unit questionnaire the authors found evidence of self-reported change in a majority of students as evidenced by these responses:

I used to think sustainable fashion was a marketing tool for business... Now I think it is really something some brands are pursuing to help the people, the environment and the world'

'I used to think brands mainly greenwash and use ethics as a means to appeal to consumers. Now I think it can be a valued and authentic part of a brand.'

Of more significance were the responses to questions about students' intended future behaviour which again showed most students had developed their social conscience and sustainability literacies as evidenced by these responses:

'I will make sure I apply the things that I have learnt about ethics and sustainability.'

'I will open a sustainable social enterprise'.

'I will devote my career to try to find a better solution with ever-changing fashion.'

\section{Conclusions}

The authors hope that these initiatives show that through setting clear objectives for educational initiatives meaningful sustainable fashion education pedagogies can be implemented creating an open and inspiring environment for generating rich discussions and ideas. From the case studies reported here and best practices some common strategies emerged that may help to facilitate and achieve better future results summarised here:

- Facilitate awareness and knowledge - supplying students with pre-reading and/or video resources helps to contextualize sustainable fashion projects and assists in balancing uneven knowledge levels between students. 
- Additional actions - visits to expert talks, retail outlets, headquarters and others locations directly connected to sustainable fashion engage students in experiential learning. By experiencing key industry experts first-hand students were deeply motivated to engage with their projects.

- Complementary courses - the different and complementary perspectives of business and design are valuable. As a business school, we tend to focus on business practices and models, however, a key way to incorporate sustainability into the core of a brand is to address design as an integral part of the process. A sustainable approach must incorporate innovation and the adoption of a creative approach to maximize the use of eco-friendly materials and processes, to minimize textile waste and energy use, and sustain and empower local communities. By adopting a design mentality and working collaboratively across all fields of the design, marketing and supply chains may reveal novel possibilities where limits are traditionally placed.

In conclusion, to work sustainably is to challenge convention and find new ways of working that achieve ecological, social and cultural balance that is in tune with human behaviour. Or in the words of one of the student respondents:

'Ethical and sustainable fashion will be one of the major trends in the coming ten years; every stakeholder should start to rethink the ways and methods they have been using.'

A statement that applies to teaching and learning as much as it does to the fashion industry we study; we should work towards developing sustainability literate staff, students and alumni through innovative pedagogies with sustainability and ethics at their core.

\section{Bibliography}

Barber, N. A., Wison, F., Venkatachalam, V., Cleaves, S. M. and Garnhma, J. (2014). Integrating sustainability into business curricula: University of New Hampshire case study. International Journal of Sustainability in Higher Education 15:4, pp473-493.

Basit, T.N., (2003). Manual or Electronic? The role of Coding in Qualitative Data Analysis. Educational Researcher. 45:2, pp143-154

Brinkmann, J., Sims, R. R., \& Nelson, L. J. (2011). Business ethics across the curriculum. Journal of Business Ethics Education, 8, 83-104.

Fletcher, K. (2008). Sustainable Fashion and Textiles: Design Journeys. Oxford: Earthscan

Goldberg, M. (2009). Social Conscience. In The Handbook of Sustainability Literacy: multimedia version. (Edited by Poppy Villiers-Stuart and Arran Stibbe) available online http://arts.brighton.ac.uk/stibbe-handbook-of-sustainability

Green Gown Award (2015). https://www.youtube.com/watch?v=1MjmpB-f-Sc 
Hammersley, M. (1998). Reading Ethnographic Research: A Critical Guide. London: Longman.

Jarvis, A. (2016). Shiny Happy People. ES Magazine $22^{\text {nd }}$ April.

Lutz, K (2011), What makes Patagonia "the Coolest Company on the Planet"? www.opportunitygreen.com, accessed 27.11.2011

Moisander, J. and Pesonen, S. (2002). Narratives of sustainable ways of living: constructing the self and the other as a green consumer. Management Decision, 40:4, pp329-342

Porter \& Kramer (2011). Creating Shared Value. Harvard Business Review, JanuaryFebruary, 62-77.

Robertson, M., Line, M., Jones, S. \& Thomas, S. (2000). International Students, Learning Environments and Perceptions: a case study using the Delphi technique. Higher Education Research and Development, 19:1, pp111-134.

Robinson, Z. (2009) Greening Business: the ability to drive environmental and sustainability improvements in the workplace. In The Handbook of Sustainability Literacy: multimedia version. (Edited by Poppy Villiers-Stuart and Arran Stibbe) available online http://arts.brighton.ac.uk/stibbe-handbook-of-sustainability

Shaw, D. S., Hogg, G., Wilson, E., Shiu, E. \& Hassan, L.M. (2004). Fashion victim: The impact of fair trade concerns on clothing choice. Journal of Strategic Marketing. 14(4), 427-440.

Stibbe, A. and Luna, H. (2009) Introduction. In The Handbook of Sustainability Literacy: multimedia version. (Edited by Poppy Villiers-Stuart and Arran Stibbe) available online http://arts.brighton.ac.uk/stibbe-handbook-of-sustainability

Storbacka, K., Strandvik, T. and Gronroos, C. (1994). Managing Customer Relationships for Profit: The Dynamics of Relationship Quality. International Journal of Service Industry Management. 5:5, pp21-38.

UN PRME News. (2016). Global Survey Shows Widespread Support for Business Ethics in $\begin{array}{llll}\text { School Curricular } & 11 & \text { August } & 2016\end{array}$ http://www.unprme.org/news/index.php?newsid=422\#.V63WM2VS2gi

Wayman, S. (2009). Futures Thinkinng. In The Handbook of Sustainability Literacy: multimedia version. (Edited by Poppy Villiers-Stuart and Arran Stibbe) available online http://arts.brighton.ac.uk/stibbe-handbook-of-sustainability 
Yeung, M. C. H., Ging, L. and Ennew, C. T. (2002) Customer satisfaction and profitability: A reappraisal of the nature of the relationship. Journal of Targeting, Measurement and Analysis for Marketing. 11:1, pp24-33.

Yin, R. K. (2003). Applications of case study research (2nd ed.), London: Sage. 